\title{
Seasonal Changes in Luteal Progesterone Concentration and mRNA Expressions of Progesterone Synthesis-related Proteins in the Corpus Luteum of Mares
}

\author{
Keisuke KOZAI ${ }^{1)}$, Takuo HOJO ${ }^{1)}$, Masashi TAKAHASHI ${ }^{2)}$, Tomas J ACOSTA ${ }^{1)}$, Yasuo NAMBO ${ }^{3)}$ \\ and Kiyoshi OKUDA ${ }^{1)}$ \\ 1) Laboratory of Reproductive Physiology, Graduate School of Natural Science and Technology, Okayama University, \\ Okayama 700-8530, Japan \\ 2) National Agricultural Research Center for Kyushu Okinawa Region, Kumamoto 861-1192, Japan \\ 3) Hidaka Training and Research Center, Japan Racing Association, Urakawa 057-0171, Japan
}

\begin{abstract}
Although circulating progesterone $\left(\mathrm{P}_{4}\right)$ levels tend to change with the season, little is known about the seasonal changes of $\mathrm{P}_{4}$ synthesis-related proteins in the corpus luteum (CL) of mares. To examine these changes, seventy-four ovaries containing a CL were collected from Anglo-Norman mares at a local abattoir in Kumamoto, Japan $\left(\sim \mathrm{N} 32^{\circ}\right)$, five times during one year. The stages of the CLs were classified as early, mid and regressed by macroscopic observation of the CL and follicles. The mid CL, which had the highest $\mathrm{P}_{4}$ concentration, was used to evaluate the seasonal changes in $\mathrm{P}_{4}$ synthesis. The luteal $\mathrm{P}_{4}$ concentration and mRNA expression of luteinizing hormone receptor (LHCGR) were lowest during early winter and highest during late winter. The mRNA expressions of steroidogenic acute regulatory protein (StAR), P450 cholesterol side-chain cleavage enzyme (P450scc) and 3 $\beta$-hydroxysteroid dehydrogenase/ $\triangle 5-\Delta 4$ isomerase $(3 \beta-H S D)$ were lowest during early winter and increased during late winter. These results suggest that $\mathrm{P}_{4}$ synthesis in the $\mathrm{CL}$ is affected by the seasonal changes in the mRNA expressions of $\mathrm{P}_{4}$ synthesis-related proteins in mares.
\end{abstract}

Key words: Corpus luteum, Mares, Progesterone, Reproductive seasonality, Steroidogenesis

(J. Reprod. Dev. 58: 393-397, 2012)

$\mathbf{M}$ ares are seasonal breeders in which day length (DL) is one of the main environmental factors controlling reproductive seasonality [1-3]. The reproductive activity of mares reaches a peak during summer, then decreases during autumn and eventually stops through winter as DL decreases. January 1 in the Northern Hemisphere and August 1 in the Southern Hemisphere are used as the official birth dates for many breeds, especially for racing breeds [4]; therefore, the exposure of mares to artificial light has been used to hasten the reproductive season. Thus, studying reproductive seasonality in mares is relevant for the equine industry.

In mammals, the corpus luteum (CL) is an endocrine organ producing progesterone $\left(\mathrm{P}_{4}\right)$, which is essential for the establishment and maintenance of pregnancy. Although several studies have examined seasonal changes in circulating $\mathrm{P}_{4}$ concentration in mares, the reported results are not consistent, i.e., the circulating $\mathrm{P}_{4}$ concentration has been reported to decrease [5-7], increase [8] or remain unchanged [9] from the breeding to non-breeding season. Therefore, the effects of season on $\mathrm{P}_{4}$ synthesis in the CL of mares remain unclear.

Luteal $\mathrm{P}_{4}$ production is regulated by several $\mathrm{P}_{4}$ synthesis-related proteins [10]. Luteinizing hormone (LH) secreted by the anterior pituitary is the main regulator of luteal function. LH acts through its

Received: January 25, 2012

Accepted: March 7, 2012

Published online in J-STAGE: April 13, 2012

(C)2012 by the Society for Reproduction and Development

Correspondence: K Okuda (e-mail: kokuda@cc.okayama-u.ac.jp) specific cell surface receptor (LHCGR) and stimulates $\mathrm{P}_{4}$ production by the CL in ewes [11], rats, sows [12], cows [13] and mares [14]. Steroidogenic acute regulatory protein (StAR) transfers cholesterol from the outer to inner mitochondrial membrane, allowing enzymatic cleavage of the side chain of cholesterol to pregnenolone by $\mathrm{P} 450$ cholesterol side-chain cleavage (P450scc). Pregnenolone is then transported to the smooth endoplasmic reticulum, which is usually closely associated with mitochondria, where $3 \beta$-hydroxysteroid dehydrogenase $/ \Delta 5-\Delta 4$ isomerase ( $3 \beta-H S D)$ converts pregnenolone to $\mathrm{P}_{4}$.

In the present study, we examined the seasonal changes in luteal $\mathrm{P}_{4}$ concentration and mRNA expressions of $\mathrm{P}_{4}$ synthesis-related proteins in the CL of mares.

\section{Materials and Methods}

\section{Collection of equine CL}

Seventy-four Anglo-Norman mares of various ages and weighing approximately $1,000 \mathrm{~kg}$, which were imported from Canada and then fattened in a ranch adjacent to an abattoir $\left(\sim \mathrm{N} 32^{\circ}\right)$ in Kumamoto, Japan, for at least two years before exsanguination, were utilized in the present study. Mares were exposed to ambient light conditions. Seventy-four ovaries containing a CL were collected from randomly designated cyclic mares at the abattoir in accordance with protocols approved by the local institutional animal care and use committee during spring (April, DL: 12.8-13.3 h), summer (July, DL: 13.8-14.1 h), autumn (September-October, DL: 11.5-12.0 h), early winter 
(December, DL: 10.0-10.1 h) and late winter (January-February, DL: $10.4-10.6 \mathrm{~h}$ ). Ovulation rates, which were defined as the proportion of mares with ovaries containing a CL to the number of mares sacrificed, were $75.8 \%$ in spring, $95.4 \%$ in summer, $92.2 \%$ in autumn, $90.5 \%$ in early winter (before winter solstice) and $62.5 \%$ in late winter (after winter solstice). Mares possessing ovaries with a macroscopic abnormality including anovulatory hemorrhagic follicles were eliminated. The ovulation rate was high even in late winter. However, this is not surprising due to the fact that mares with a high body condition score (BCS) continued to ovulate throughout the winter or had significant follicular activity in the ovaries [15]. The mares used in the present study weighed approximately $1,000 \mathrm{~kg}$ and were expected to have a high BCS. After midsagittal sectioning, the CLs were classified as being in the early, mid and regressed luteal stages ( $n=3-6 /$ stage) by macroscopic observation of the CL and follicles as described previously $[16,17]$. Briefly, the early CL had a corpus hemorrhagicum; the mid CL had a solid, although trabeculated, appearance; and the regressed CL was straw colored and associated with follicles $>35 \mathrm{~mm}$ in diameter. Following determination of the stages, CL tissues were immediately separated from the ovaries, rinsed with cold sterile saline, frozen rapidly in liquid nitrogen and then stored at $-80 \mathrm{C}$ until being processed for $\mathrm{P}_{4}$ and RNA extraction.

\section{$P_{4}$ extraction}

$\mathrm{P}_{4}$ was extracted from luteal tissues as described previously [18]. Briefly, approximately $0.2 \mathrm{~g}$ of minced luteal tissue was added to 2 $\mathrm{ml}$ of ethanol. The tissues were then homogenized 5 times for $10 \mathrm{sec}$ on ice by a tissue homogenizer (Physcotron; NITI-ON, Chiba, Japan; NS-50) and 3 times for $1 \mathrm{~min}$ on ice by an ultrasonic homogenizer. The suspension was incubated at room temperature for $1 \mathrm{~h}$. After centrifugation $(1,700 \mathrm{rpm}$ for $30 \mathrm{~min}$ at $4 \mathrm{C})$, the supernatant was evaporated in a vacuum oven at $50 \mathrm{C}$, and the residue was dissolved in $2 \mathrm{ml}$ of assay buffer for enzyme immunoassay (EIA).

\section{$P_{4}$ determination}

Concentrations of $\mathrm{P}_{4}$ were determined directly from the tissue extracts with an EIA as described previously [19]. The standard curve ranged from 0.391 to $100 \mathrm{ng} / \mathrm{ml}$, and the effective dose of the assay for $50 \%$ inhibition (ED50) was $4.5 \mathrm{ng} / \mathrm{ml}$. The intra- and interassay coefficients of variation were 5.6 and $6.9 \%$, respectively.

Since the $\mathrm{P}_{4}$ concentration in the luteal tissues reached the highest levels at the mid luteal stage (data not shown), the mid CL was used to evaluate the seasonal changes in $\mathrm{P}_{4}$ synthesis in mares.

\section{Real-time PCR}

Total RNA was extracted from luteal tissue using TRIzol Reagent (Invitrogen, Carlsbad, CA, USA; 15596-026) according to the manufacturer's instructions. One $\mu \mathrm{g}$ of each total RNA was reverse transcribed using a ThermoScript ${ }^{\mathrm{TM}}$ RT-PCR System (Invitrogen; 11146-016). Gene expression was measured by real-time PCR using a MyiQ (Bio-Rad Laboratories, Melville, NY, USA) and SYBR $^{\circledR}$ Premix Ex Taq ${ }^{\mathrm{TM}}$ II (RR081B, TaKaRa) starting with 2 ng of reverse-transcribed total RNA as described previously [20]. Briefly, for quantification of the mRNA expression levels, the primer length (20 or $21 \mathrm{bp}$ ) and GC contents of each primer (50-55\%) were synthesized using an online software package as shown in Table 1, and the primer specificity was validated by BLAST. To determine the most stable internal control gene under our experimental conditions, three potential housekeeping genes were initially considered ( $\beta$-actin, $\beta 2$-microglobulin and glyceraldehyde-3-phosphate dehydrogenase; GAPDH). GAPDH gene transcription was unaffected by our experimental conditions and was therefore selected as the internal control. The primers for LHCGR, StAR, P450scc, 3 $\beta$-HSD and GAPDH generated specific 122-bp, 120-bp, 123-bp, 132-bp and 135-bp products, respectively. Each PCR yielded only a single amplification product. PCR was performed under the following conditions: $95 \mathrm{C}$ for $3 \mathrm{~min}$, followed by 45 cycles of $94 \mathrm{C}$ for $15 \mathrm{sec}, 55 \mathrm{C}$ for $20 \mathrm{sec}$ and $72 \mathrm{C}$ for $15 \mathrm{sec}$. Use of SYBR ${ }^{\circledR}$ Premix Ex Taq ${ }^{\mathrm{TM}} \mathrm{II}$ at elevated temperatures resulted in reliable and sensitive quantification of the RT-PCR products with high linearity (Pearson correlation coefficient $r>0.99$ ). The expression of each gene was evaluated based on the $G A P D H$ mRNA expression in the individual samples.

\section{Statistical analysis \\ All experimental data are shown as means \pm SEM. The statistical significance of differences in luteal $\mathrm{P}_{4}$ concentration and mRNA expressions of $L H C G R, S t A R, P 450 s c c$ and $3 \beta-H S D$ were assessed by analysis of variance (ANOVA) followed by a Fisher protected least- significant difference procedure (PLSD) as a multiple comparison test.}

Table 1. Primers used in real-time PCR

\begin{tabular}{|c|c|c|c|c|}
\hline Gene & Primer & Sequence & Accession No. & Product size \\
\hline \multirow[t]{2}{*}{ LHCGR } & Forward & 5'-TTGCCACATCATCCTATTCTC-3' & AY464091 & $122 \mathrm{bp}$ \\
\hline & Reverse & 5'-TTCTTTTGTTGGCAAGTTTCT-3' & & \\
\hline \multirow[t]{2}{*}{ StAR } & Forward & 5'-CGAGCAGAAAGGTGTCATCA-3' & NM_001081800 & $120 \mathrm{bp}$ \\
\hline & Reverse & 5'-CATCCCTTGAGGTCAATGCT-3' & & \\
\hline \multirow[t]{2}{*}{ P450sce } & Forward & 5'-GCCTCCTAGCAAGCAACAAG-3' & NM_001082521 & $123 \mathrm{bp}$ \\
\hline & Reverse & 5'-TGCGTGCTATCTCGTACAGG-3' & & \\
\hline \multirow[t]{2}{*}{$3 \beta-H S D$} & Forward & 5'-TGGCATCCTGACACACAACT-3' & D89666 & $132 \mathrm{bp}$ \\
\hline & Reverse & 5'-AACTGTCCTTGGATGCTTGG-3' & & \\
\hline \multirow[t]{2}{*}{$G A P D H$} & Forward & 5'-CGACCACTTTGTCAAGCTCA-3' & NM_001163856 & $135 \mathrm{bp}$ \\
\hline & Reverse & 5'-TCCTTCTCTTGCTGGGTGAT-3' & & \\
\hline
\end{tabular}




\section{Results}

The $\mathrm{P}_{4}$ concentration (Fig. 1) and mRNA expression of $L H C G R$ (Fig. 2A) were highest during late winter (both $\mathrm{P}<0.05$ ). The mRNA expression of StAR was higher during spring than during early winter and was higher during summer than during autumn and early winter (Fig. 2B; $\mathrm{P}<0.05$ ). The mRNA expression of $P 450 \mathrm{scc}$ was higher during spring than during autumn and early winter and was higher during summer and late winter than during early winter (Fig. $2 \mathrm{C}$; $\mathrm{P}<0.05$ ). The mRNA expression of $3 \beta$-HSD was higher during spring than during autumn and early winter (Fig. 2D; $<<0.05$ ). The mRNA expressions of StAR, P450scc and $3 \beta$-HSD decreased from summer to early winter and then increased to late winter in the same fashion.

\section{Discussion}

The preceding data demonstrate that both the luteal $\mathrm{P}_{4}$ concentration and mRNA expressions of $\mathrm{P}_{4}$ synthesis-related proteins in the $\mathrm{CL}$ changed seasonally.

In most mammals, $\mathrm{LH}$ is a major luteotropic hormone that stimulates $\mathrm{P}_{4}$ production by the CL [10-14, 21, 22]. In mares, administration of $\mathrm{GnRH}$, eLH or hCG increased circulating $\mathrm{P}_{4}$ concentrations in vivo [23-26]. In addition, in vitro studies demonstrated that either eLH or hCG increased the $\mathrm{P}_{4}$ production by equine luteal cells [14, 24]. Moreover, treatment of mares with an antiserum against equine gonadotropins during diestrous decreased the luteal size [27, 28], and treatment of mares with a GnRH antagonist during diestrous

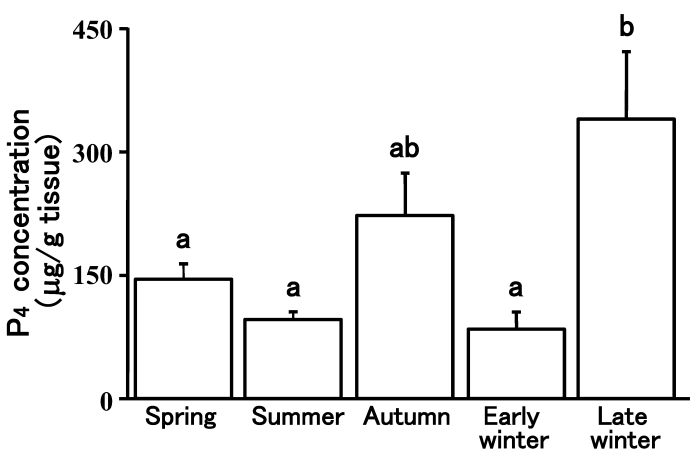

Fig. 1. Effect of season on luteal $\mathrm{P}_{4}$ concentration. All experimental data are shown as means \pm SEM. Different letters indicate significant differences $(\mathrm{P}<0.05)$ as determined by ANOVA followed by Fisher's PLSD as a multiple comparison test.

decreased the circulating $\mathrm{P}_{4}$ concentrations $[29,30]$. These findings indicate that $\mathrm{LH}$ stimulates the production of $\mathrm{P}_{4}$ by the $\mathrm{CL}$ and support luteal function in mares, as shown in other species [10, $21,22]$. In mares, circulating LH concentrations were high during summer and low during winter [31]. Therefore, we expected that the $\mathrm{P}_{4}$ concentration in the luteal tissue would be high during summer and low during winter. In the present study, however, $\mathrm{P}_{4}$ concentrations in the luteal tissues were low during summer and
A
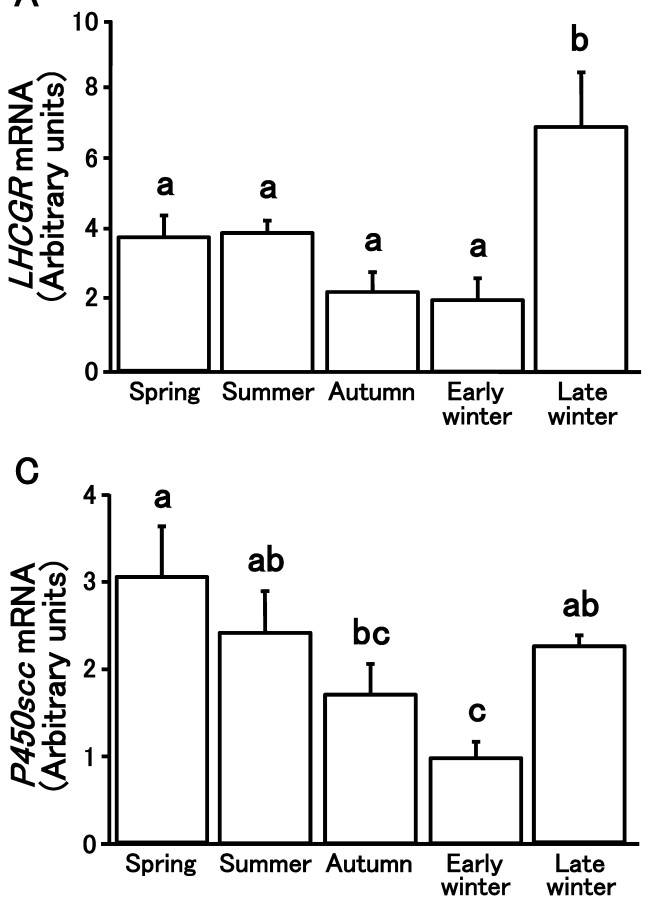

B
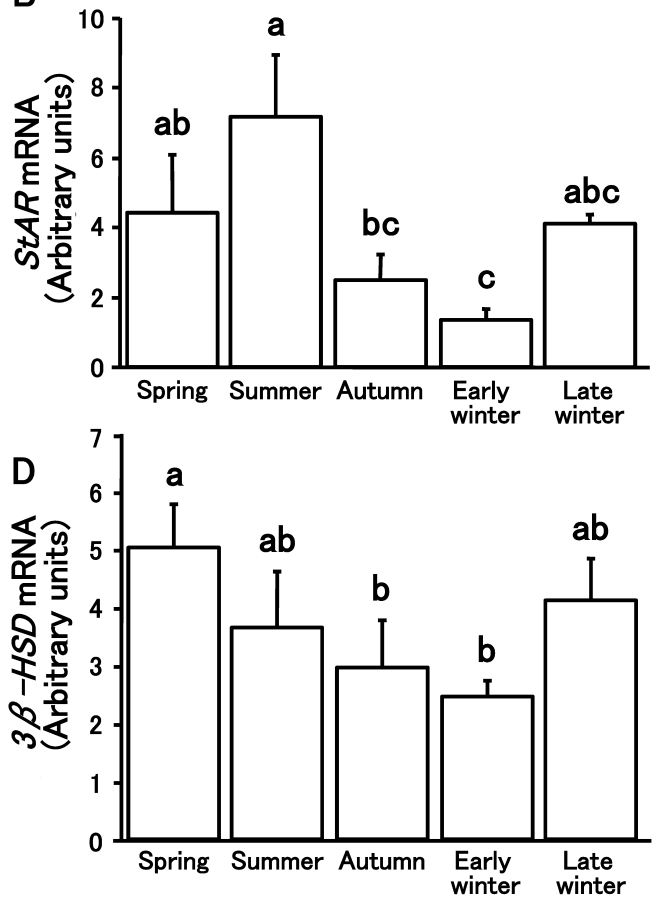

Fig. 2. Effects of season on mRNA expressions of (A) LHCGR, (B) StAR, (C) P450scc and (D) $3 \beta$ - HSD in the mid CL. All experimental data are shown as means \pm SEM. Different letters indicate significant differences $(\mathrm{P}<0.05)$ as determined by ANOVA followed by Fisher's PLSD as a multiple comparison test. 
early winter, and high during late winter. The luteal $\mathrm{P}_{4}$ concentration was calculated as the $\mathrm{P}_{4}$ content per one gram of tissue. Therefore, if the CL during summer is heavier than during late winter, total $\mathrm{P}_{4}$ production from the CL may be higher during summer than during late winter. Thus, a discrepancy between the results of the present and previous studies [31] may be due to the difference in luteal tissue weight between seasons. Unfortunately, we did not weigh the luteal tissue in the present study. A further study is needed to clarify this point. In addition, since LH acts through LHCGR, which is present on the cell surface, it could be assumed that changes in the levels of LHCGR expression in luteal cells modify the stimulatory effect of $\mathrm{LH}$ on $\mathrm{P}_{4}$ production by the CL. In the present study, the luteal $\mathrm{P}_{4}$ concentration and mRNA expression of $L H C G R$ in the CL showed similar seasonal changes and were highest during late winter. This finding suggests that an increase in the sensitivity of the CL to LH results in increasing $\mathrm{P}_{4}$ concentrations in the luteal tissues during late winter. Administration of prostaglandin $\mathrm{F} 2 \alpha$ reduced circulating $\mathrm{P}_{4}$ concentrations and the mRNA expression of $L H C G R$ in the CL of ewes [32], cows [33] and mares [34]. Moreover, circulating and luteal $\mathrm{P}_{4}$ concentrations were highly correlated with the number and affinity of LHCGR in the CL of mares [35]. The findings of the present and previous studies strongly suggest that $\mathrm{P}_{4}$ production in the CL is closely related to LHCGR expression in mares. However, the mechanisms regulating LHCGR expression remain unknown. Further studies are needed to clarify the factors regulating LHCGR expression in the CL of mares.

We demonstrated in the present study for the first time the effects of seasons on the mRNA expressions of StAR, P450scc and $3 \beta-H S D$ in the CL of mares. The mRNA expressions of StAR and $3 \beta-H S D$ decreased from summer and spring to early winter, respectively, and then tended to increase during late winter, whereas the mRNA expression of $P 450 \mathrm{scc}$ decreased from spring to early winter, and then increased during late winter. In mares, circulating LH concentrations decreased from summer to winter and then remained at a low level until the following spring [31]. In the present study, the mRNA expressions of StAR and $3 \beta-H S D$, but not P450scc, showed seasonal changes similar to those of the circulating LH concentrations reported previously [31]. The mRNA expressions of StAR and $3 \beta-H S D$ may be regulated by $\mathrm{LH}$ in mares. In addition, mRNA expressions of StAR, P450scc and $3 \beta$-HSD tended to increase during late winter when circulating LH concentrations remained low [31]. The slight increases in the mRNA expressions of StAR, P450scc and $3 \beta-H S D$ might result from an increase in the sensitivity of the CL to LH due to an elevation in LHCGR expression, supporting the idea that LH stimulates the mRNA expressions of StAR, P450scc and 3 $\beta-H S D$ in the CL of mares. Furthermore, the changes in mRNA expressions of StAR, P450scc and $3 \beta-H S D$ from autumn to early winter were coincident with those of $\mathrm{P}_{4}$ concentrations in the luteal tissues. These findings confirmed that $\mathrm{P}_{4}$ production by the $\mathrm{CL}$ is associated with the mRNA expressions of StAR, P450scc and $3 \beta-H S D$, as suggested earlier in mares [34, 36, 37]. Taken together, these findings suggest that $\mathrm{LH}$ regulates the mRNA expressions of StAR, P450scc and $3 \beta$-HSD, leading to the seasonal changes in luteal function in mares.

In conclusion, we demonstrated that both the luteal $\mathrm{P}_{4}$ concentration and mRNA expressions of $\mathrm{P}_{4}$ synthesis-related proteins in the CL changed seasonally and that there was a close relationship between the luteal $\mathrm{P}_{4}$ concentration and the mRNA expressions of $\mathrm{P}_{4}$ synthesis-related proteins in the CL. The overall findings suggest that the capacity of the CL to synthesize $\mathrm{P}_{4}$ is affected by the seasonal changes in the mRNA expressions of $\mathrm{P}_{4}$ synthesis-related proteins in mares.

\section{Acknowledgments}

This study was supported in part by the Equine Research Institute, Japan Racing Association.

\section{References}

1. Kooistra LH, Ginther OJ. Effect of photoperiod on reproductive activity and hair in mares. Am J Vet Res 1975; 36: 1413-1419. [Medline]

2. Sharp DC, Ginther OJ. Stimulation of follicular activity and estrous behavior in anestrous mares with light and temperature. J Anim Sci 1975; 41: 1368-1372. [Medline]

3. Sharp DC, Kooistra L, Ginther OJ. Effects of artificial light on the oestrous cycle of the mare. J Reprod Fertil Suppl 1975; 23: 241-246. [Medline]

4. Ginther OJ. Reproductive seasonality. In: Reproductive Biology of the Mare: Basic and Applied Aspects. $2^{\text {nd }}$ ed. Wisconsin: Equiservices; 1992: 105-134.

5. King SS, Douglas BL, Roser JF, Silvia WJ, Jones KL. Differential luteolytic function between the physiological breeding season, autumn transition and persistent winter cyclicity in the mare. Anim Reprod Sci 2010; 117: 232-240. [Medline] [CrossRef]

6. King SS, Neumann KR, Nequin LG, Weedman BJ. Time of Onset and Ovarian State Prior to Entry into Winter Anestrus. J Equine Vet Sci 1993; 13: 512-515. [CrossRef]

7. Nagy P, Huszenicza G, Reiczigel J, Juhasz J, Kulcsar M, Abavary K, Guillaume D. Factors affecting plasma progesterone concentration and the retrospective determination of time of ovulation in cyclic mares. Theriogenology 2004; 61: 203-214. [Medline] [CrossRef]

8. Okolski A, Bielanski AB. Seasonal fluctuations of the plasma progesterone levels in mares with similar ovarian morphology. Int Cong Anim Reprod Artif Insem 1980; Madrid; 4: $13-15$

9. Townson DH, Pierson RA, Ginther OJ. Characterization of plasma progesterone concentrations for two distinct luteal morphologies in mares. Theriogenology 1989; 32: 197-204. [Medline] [CrossRef]

10. Niswender GD, Juengel JL, Silva PJ, Rollyson MK, McIntush EW. Mechanisms controlling the function and life span of the corpus luteum. Physiol Rev 2000; 80: 1-29 [Medline]

11. Rodgers RJ, O'Shea JD, Findlay JK. Progesterone production in vitro by small and large ovine luteal cells. J Reprod Fertil 1983; 69: 113-124. [Medline] [CrossRef]

12. Tekpetey FR, Armstrong DT. Steroidogenic response of rat and pig luteal cells to estradiol-17ß and catecholestrogens in vitro. Biol Reprod 1991; 45: 498-505. [Medline] [CrossRef]

13. Nishimura R, Shibaya M, Skarzynski DJ, Okuda K. Progesterone stimulation by LH involves the phospholipase-C pathway in bovine luteal cells. J Reprod Dev 2004; 50: 257-261. [Medline] [CrossRef]

14. Galvao AM, Ramilo DW, Skarzynski DJ, Lukasik K, Tramontano A, Mollo A, Mateus LM, Ferreira-Dias GM. Is FAS/Fas ligand system involved in equine corpus luteum functional regression? Biol Reprod 2010; 83: 901-908. [Medline] [CrossRef]

15. Gentry LR, Thompson DL Jr., Gentry GT Jr., Davis KA, Godke RA, Cartmill JA. The relationship between body condition, leptin, and reproductive and hormonal characteristics of mares during the seasonal anovulatory period. J Anim Sci 2002; 80: 2695-2703. [Medline]

16. Ginther OJ. Characteristic of the ovulatory season. In: Reproductive Biology of the Mare: Basic and Applied Aspects. $2^{\text {nd }}$ ed. Wisconsin: Equiservices; 1992: 173-232.

17. Ferreira-Dias G, Bravo PP, Mateus L, Redmer DA, Medeiros JA. Microvascularization and angiogenic activity of equine corpora lutea throughout the estrous cycle. Domest Anim Endocrinol 2006; 30: 247-259. [Medline] [CrossRef]

18. Wijayagunawardane MPB, Miyamoto A, Cerbito WA, Acosta TJ, Takagi M, Sato K. Local distributions of oviductal estradiol, progesterone, prostaglandins, oxytocin and endothelin-1 in the cyclic cow. Theriogenology 1998; 49: 607-618. [Medline] [CrossRef]

19. Okuda K, Uenoyama Y, Fujita Y, Iga K, Sakamoto K, Kimura T. Functional oxytocin receptors in bovine granulosa cells. Biol Reprod 1997; 56: 625-631. [Medline] [CrossRef]

20. Sakumoto R, Komatsu T, Kasuya E, Saito T, Okuda K. Expression of mRNAs for interleukin-4, interleukin-6 and their receptors in porcine corpus luteum during the estrous cycle. Domest Anim Endocrinol 2006; 31: 246-257. [Medline] [CrossRef] 
21. Juengel JL, Niswender GD. Molecular regulation of luteal progesterone synthesis in domestic ruminants. J Reprod Fertil Suppl 1999; 54(Suppl): 193-205. [Medline]

22. Niswender GD. Molecular control of luteal secretion of progesterone. Reproduction 2002; 123: 333-339. [Medline] [CrossRef]

23. Johnson AL, Becker SE, Roma ML. Effects of gonadotrophin-releasing hormone and prostaglandin F-2 $\alpha$ on corpus luteum function and timing of the subsequent ovulation in the mare. J Reprod Fertil 1988; 83: 545-551. [Medline] [CrossRef]

24. Kelly CM, Hoyer PB, Wise ME. In-vitro and in-vivo responsiveness of the corpus luteum of the mare to gonadotrophin stimulation. J Reprod Fertil 1988; 84: 593-600. [Medline] [CrossRef]

25. Ginther OJ. Endocrinology of the ovulatory season. In: Reproductive Biology of the Mare: Basic and Applied Aspects. 2nd ed. Wisconsin: Equiservices; 1992: 233-290.

26. Watson ED, Colston M, Broadley C. LH and progesterone concentrations during diestrus in the mare and the effect of hCG. Theriogenology 1995; 43: 1325-1337. [CrossRef]

27. Pineda MH, Ginther OJ, McShan WH. Regression of corpus luteum in mares treated with an antiserum against an equine pituitary fraction. Amer J Vet Res 1972; 33: 17671773. [Medline]

28. Pineda MH, Garcia MC, Ginther OJ. Effect of antiserum against an equine pituitary fraction on corpus luteum and follicles in mares during diestrus. Amer J Vet Res 1973; 34: 181-183. [Medline]

29. Watson ED, Pedersen HG, Thomson SRM, Fraser HM. Control of follicular development and luteal function in the mare: effects of a GnRH antagonist. Theriogenology 2000; 54: 599-609. [Medline] [CrossRef]

30. Evans MJ, Alexander SL, Irvine CH, Kitson NE, Taylor TB. Administration of a gonadotropin-releasing hormone antagonist to mares at different times during the lutea phase of the estrous cycle. Anim Reprod Sci 2011; 127: 188-196. [Medline] [CrossRef]

31. Turner DD, Garcia MC, Ginther OJ. Follicular and gonadotropic changes throughout the year in pony mares. Am J Vet Res 1979; 40: 1694-1700. [Medline]

32. Guy MK, Juengel JL, Tandeski TR, Niswender GD. Steady-state concentrations of mRNA encoding the receptor for luteinizing hormone during the estrous cycle and following prostaglandin F(2alpha) treatment of ewes. Endocrine 1995; 3: 585-589. [Medline] [CrossRef]

33. Tsai SJ, Kot K, Ginther OJ, Wiltbank MC. Temporal gene expression in bovine corpora lutea after treatment with PGF2alpha based on serial biopsies in vivo. Reproduction 2001; 121: 905-913. [Medline] [CrossRef]

34. Beg MA, Gastal EL, Gastal MO, Ji S, Wiltbank MC, Ginther OJ. Changes in steadystate concentrations of messenger ribonucleic acids in luteal tissue during prostaglandin F2alpha induced luteolysis in mares. Anim Reprod Sci 2005; 90: 273-285. [Medline] [CrossRef]

35. Roser JF, Evans JW. Luteal luteinizing hormone receptors during the postovulatory period in the mare. Biol Reprod 1983; 29: 499-510. [Medline] [CrossRef]

36. Watson ED, Bae SE, Al-Zi'abi MO, Hogg CO, Armstrong DG. Expression of mRNA encoding insulin-like growth factor binding protein-2 (IGFBP-2) during induced and natural regression of equine corpora lutea. Theriogenology 2005; 64: 1371-1380. [Medline] [CrossRef]

37. Slough TL, Rispoli LA, Carnevale EM, Niswender GD, Bruemmer JE. Temporal gene expression in equine corpora lutea based on serial biopsies in vivo. J Anim Sci 2011; 89: 389-396. [Medline] [CrossRef] 